\title{
Sendromik Olmayan Konjenital Yarık Damak-Dudak Bulunan Hastalarda Kopya Sayısı Varyasyonlarının Belirlenmesi
}

Determination of Copy Number Variations in Non-Syndromic Congenital Cleft Palate - Lip Patients

\section{Emine İkbal Atlı, Engin Atlı, Sinem Yalçıntepe, Selma Demir, Yasemin Özen, Hakan Gürkan}

Trakya Üniversitesi Tip Fakültesi Tibbi Genetik Ana Bilim Dal, Edirne, Türkiye

Correspondence:

Emine İkbal ATLI

Trakya Üniversitesi Tip Fakültesi Tibbi Genetik Ana Bilim Dalı, Edirne, Türkiye

e-mail: emine.ikbal@gmail.com

\section{Özet}

Dudak damak yarığı en sık görülen kraniyofasiyal anomalidir. Olguların \%70 inde eşlik eden anomali bulunmaz ve non sendromik dudak damak yarığı olarak adlandırılır. Genetik biliminde moleküler ve kantitatif olarak meydana gelen gelişmeler bu patolojinin sendromik ve sendromik olmayan her iki tipinde de genetik mekanizmalarının rol oynuyor olabileceğini düşündürmektedir Sendromik olmayan yarık dudak/damak, embriyonik dönemde gerçekleşen yaygın bir gelişimsel anormalliktir. Bu çalışma, yarık dudak/damak patogenezinde yer alan kopya sayısı değişimlerine bağlı genetik anormallikleri tanımlamak amacı taşımaktadır. Genom çapında kopya sayısı varyasyonlarını saptama hedefli CytoScan 180K dizisi kullanılarak yaptı̆ı̆ııı çalışma, 1-15 yaşları arasındaki 17 yarık damak dudak olan hasta örneği ile gerçekleştirilmiștir. Yedi önemli kopya sayısı değişimi saptanmıştır. Bu değişimler yarık damak dudak hastalarında, duplikasyonlardan (9p23-p24, 18q12.1, Xp22.12, Xp22.31, Yq11.21/16q24.1) ve delesyonlardan (5q21.3 ve 6p22.3-23) oluşuyordu. Genetik faktörlerin sendromik olmayan vakalarda da rol oynadığı çalışmamız ile de gösterilmiștir. Daha geniş ölçekli genom tarama çalıșmaları farklı populasyonlarda da devam etmektedir. İleriye yönelik hasta yönetiminde göz önünde tutulması gereken; aile ve akrabalarda yarık dudak ve damak bulunması halinde sonraki çocukta yarı damak dudak görülme riskinin arttığıdır. Anne babanın etkilenmediği sporadik vakalarda dahi, bir sonraki çocukta oral yarık riskinin arttığı göz önünde tutulmalı ve aile, sonraki gebelik için mutlaka bilgilendirilmelidir.

Anahtar Kelimeler: Nonsendromik dudak ve damak yarığı; genetik tanı; a-CGH; kopya sayısı değişimleri

Abstract

Cleft lip and palate is the most common craniofacial anomaly. There is no concomitant anomaly in $70 \%$ of the cases and it is called non-syndromic cleft lip and palate. Molecular and quantitative developments in the science of genetics suggest that genetic mechanisms may play a role in both syndromic and non-syndromic types of this pathology. Non-syndromic cleft lip / palate is a common developmental abnormality that occurs during the embryonic period. This study aims to define genetic abnormalities due to copy number changes in cleft lip / palate pathogenesis. Our study, using the CytoScan 180K sequence targeted to detect genome-wide copy number variations, was performed with a sample of 17 patients with cleft lip and palate aged 1-15 years. Seven significant copy number changes were detected. These changes consisted of duplications (9p23-p24, 18q12.1, Xp22.12, Xp22.31, Yq11.21/ 16q24.1) and deletions (5q21.3 and 6p22.3-23) in patients with cleft lip and palate. It has also been shown in our study that genetic factors play a role in non-syndromic cases. Larger scale genome screening studies continue in different populations as well. The important point to be kept in mind in prospective patient management is this; If there is a cleft lip and palate in the family and relatives, the risk of cleft lip and palate increases in the next child. Even in sporadic cases where parents are not affected, it should be kept in mind that the risk of oral cleft in the next child is increased and the family should be informed about the next pregnancy.

Keywords: Nonsyndromic cleft lip and palate; genetic diagnosis; a-CGH; copy number variations 


\section{Giriş}

Kraniyofasiyal malformasyonlar (CFM'ler), insanlarda en sı görülen doğum malformasyonları arasındadır ve orofasiyal yarıklar, tüm canlı doğumlarda konjenital malformasyonların yaklaşı $\% \quad 13$ 'ünü oluşturur $^{1}$. Orofasiyal yarıklar, özellikle yarık dudak (CL) ve yarık damak (CP), insanlarda en sik görülen kraniyofasiyal doğum kusurlarıdır ve önemli bir kişisel ve toplumsal yükü temsil eder. Yarıklar, ömür boyu 700 kişiden yaklaşık 1'ini etkiler. Etkilenen bireyler başlangıçta beslenme güçlükleri yaşarlar ve ayrıca konuşma, işitme ve diş problemleri yaşarlar ${ }^{2}$. Yarıklar cerrahi olarak onarılabilmesine rağmen, hastalar genellikle birden fazla kraniofasiyal ve dis ameliyatının yanı sıra konuşma ve işitme terapisine de tabi tutulur. $\mathrm{Bu}$ müdahalelere rağmen hastalar malformasyondan ömür boyu sürecek psikososyal etkiler yaşayabilir. Aslında, bu malformasyonla doğan bireyler, yaşamın her aşamasında zihinsel sağlık sorunları görülme sıklığını ve daha yüksek ölüm oranlarını görmüştür ${ }^{3}$. Ayrıca, yarık damak/dudak olan bireyde ve aile üyelerinde meme, beyin ve kolon kanserleri dâhil olmak üzere çeșitli kanser türlerinin daha yüksek riskiyle ilişkilidir ${ }^{4,5}$. Yarık etiyolojilerini anlamak, yalnızca gelișimsel biyoloji bilgimiz için değil, aynı zamanda orofasiyal yarıktan etkilenen bireyler için daha iyi tedavi ve prognoz için de önemlidir.

Dudak damak yarıkları bir sendromla ilişkili veya nonsendromik olabilirler. İzole $\mathrm{CP}$ hastaların \%50'si nonsendromik iken $\mathrm{CL}+\mathrm{CP}$ hastaların \%70'inin nonsendromik olduğu düşünülmektedir.

Dudak ve damak yarıklarının 300 civarında sendromun içerisinde yer aldığı bilinmektedir. Yark dudak ve damak anomalisinin sendromlarla birliktelik insidans1 \%3-22,4 arasındadır. Tunçbilek ve ark.yaptıkları çalışmada yarık dudak yarık damaklı olguların $\% 4.4$ 'nün sendromik olduğu saptanmıştır ve en sik Pierre Robin Sendromu görülmüştür ${ }^{6}$.

Orofasial yarıkları 4 grupta inceleyebiliriz.

I. Non sendromik yarık damak olsun olmasin yarık dudak olgusu
II. Non sendromik izole yarık damak olgusu

III. Sendromik yarı damak olsun olmasın yarık dudak olgusu

IV. Sendromik izole yarık damak olgusu

\section{Sendromik Olmayan Orofasial Yarıklar}

Orofasiyal yarık vakalarının çoğu ek özelliklerden yoksundur ve "sendromik olmayan" olarak kategorize edilir ${ }^{7}$. Birçok çalışma CL / P prevalansını bildirmiş olsa da CLP'yi CL'den ayıranlar CLP'nin CL'den iki kat daha yaygın olduğunu gözlemlemiștir ${ }^{8}$. Sendromik olmayan yarıklar arasında, CL / P erkeklerde kadınlara göre iki kat, CP kadınlarda iki kat daha s1ktır9. Dudağ ${ }^{9}$ tutan yarıkların yaklaşık \% 75'i tek taraflıdır. Tek taraflı yarıklar arasında, sol tarafi etkileyenler, sağ taraftaki yarıklara göre iki kat daha yaygındır ${ }^{10}$. İlginç bir şekilde, damak yarı̆̆ olan veya olmayan sendromik olmayan yarı dudak (NSCL / P) prevalansı da atalara göre değişir. NSCL / P en yaygın olarak Asya veya Amerika kökenli olanları (1/500 canlı doğum) ve en az yaygın olarak Afrika kökenli olanları $(1 / 2500)$ etkiler ${ }^{11}$. Kafkas populasyonları, yaklaşık 1/1000 oranında orta düzeyde bir yaygınlık oranına sahiptir ${ }^{8}$. Türkiye'de ise bu oran 1-2/1000 olarak bildirilmiştir ${ }^{12}$.

NSCL/P, çoklu genetik ve çevresel risk faktörlerinin etkileşiminden kaynaklanan genetik olarak karmaşık bir hastalıktır. Segregasyon analizi ve ikiz çalışmaları sonrasında NSCL/P'nin genetik yatkınlığ 1 desteklendi. NSCL/P, yüksek bir aile nüksü oranına sahiptir; birinci derece akrabalardaki CL riskinin, ailesinde CL geçmiși olmayan bireylere oranla 32 kat fazla olduğu tahmin edilmektedir ${ }^{13}$.

NSCL/P'ye katkıda bulunan genlerin tanımlanması, yakın zamana kadar sadece mütevazı bir başarıya sahip olan çeşitli yaklaşımlar (örneğin, bağlantı analizi, genomik yeniden düzenlemeler, aday genler, genom çapında ilişkilendirme çalışmaları) kullanılarak onlarca yıllık çalışmaların konusunu oluşturmuştur ${ }^{14}$. 
Bağlantı analizi çalışmaları, genetik lokusların hastalıkla ilişkisinin aydınlatılmasına dayanmaktadır ve büyük, multipleks ailelerde veya etkilenen akraba çiftlerinde gerçekleştirilebilirler. Bugüne kadar NSCL/P için 13 genom çapında bağlantı taraması yapılmıştır. Yedi populasyondan 388 geniş aileyi kapsayan geniş bir bağlantı çalışması ve yayınlanan bağlantı bölgesinden altısını birleştiren meta-analiz taramaları, 1q32, 2p13, 3q27-28, 9q21, 14q21-24 ve 16q24'te genom çapında ilk önemli bağlantı sonuçlarını belirlemiştir ${ }^{15}$. Devamında yapılan $9 \mathrm{q} 21$ bölgesinin ince haritalamas1, FOXE1'i bu lokustaki nedensel gen olarak tanımlamıştır ${ }^{16}$. Genomik yeniden düzenlemeler, kromozomların uygunsuz rekombinasyonundan kaynaklanır ve kromozomlar içinde veya arasında meydana gelebilecek delesyonlar, duplikasyonlar, translokasyonlar ve inversiyonlar bu değişimleri kapsar.

Dengeli yeniden düzenlemelere sahip hastalarda kırılma noktalarının analizi, CLPTM1, SATB2, SUMO1 ve FGFR1'i CL/P için aday genler olarak tanımladı ve $9 \mathrm{q}$ ve $17 \mathrm{q}$ 'yi potansiyel risk lokusları olarak gösterdi ${ }^{17}$.

Genom çapında ilişki çalı̧̧maları (GWAS), NSCL/P gibi karmaşık özelliklerle ilişkili aday genleri veya lokusları tanımlamak için tarafsız yaklaşımları için yaygın olarak kullanılmaktadır. Bugüne kadar, NSCL/P için dört bağımsız GWAS ve bir meta-analiz yayınland ${ }^{18-21}$. Birnbaum ve ark., Alman populasyonunda $8 \mathrm{q} 24$ ve NSCL/P üzerindeki belirteçler arasında son derece güçlü bir ilişki buldu ve daha sonra Amerika Birleşik Devletleri'nde de aynı çalışma tekrarlanarak bu bağlantı farklı bir popülasyonda doğrulanmış oldu ${ }^{18,19}$. Üçüncü çalışmada, Mangold ve ark. 10q25 kromozomunda VAX1 ve $17 \mathrm{q} 22$ kromozomunda $N O G$ yakınında ek önemli sinyaller belirledi ${ }^{21}$. NSCL/P'nin dördüncü GWAS'1 GENEVA Cleft Consortium çalışması olarak Beaty ve ark. tarafından gerçekleştirildi ${ }^{17}$. $\mathrm{Bu}$ çalışmanın özellikleri, bir NSCL/P GWAS'da ilk kez vaka-ebeveyn triosu kullanılması ve Avrupa, Asya ve çeşitli soy ailelerinin dâhil edilmesiydi. Tüm populasyonlar için kombine analizde, çalışma 1q32 ve 8q24 ile önceki ilişkileri doğrulad 1 ve 1 p22 ve $20 q 12$ 'de yeni lokusların belirlenmesini sağladı.

Popülasyona göre katmanlandırıldığında, 1q32, 1p22 ve 20q12'ye yakın belirteçler Asyalılarda genom çapında önem kazanırken, Avrupalılarda yalnızca 8q24 sinyali belirgin olarak farklılık göstermiştir. Daha fazla şüpheli kromozomal lokus belirlemek için, Ludwig ve ark. GENEVA Cleft Consortium ve Mangold ve ark.'nın çalışmalarını birleștirerek yayınlanmış en büyük GWAS olan bir meta-analiz gerçekleştirdi ${ }^{20,21}$.

Avrupa vaka kontrol verilerini Avrupa Amerikan trioları ile birleștirmek, altı lokusun genom çapında anlamlılığa ulaşmasıyla sonuçlanmıştır (8q24, 10q25, 17q22, 2p21, $13 \mathrm{q} 31$ ve $15 \mathrm{q} 22$ ). GENEVA çalışmasından Asya üçlülerinin eklenmesi, bu lokusların beşi için (15q22 hariç) daha küçük p-değerleri ile sonuçlandı ve bu lokusların hem Avrupa hem de Asya populasyonlarında NSCL/P'ye katkıda bulunduğunu göstermiştir. Ek olarak, altı ek bölge genom çapında önem kazanmıştır (1p36, 1p22, 1q32, 3p11, 8q21 ve 20q12). Mangold ve ark. 13q31 lokusunun yalnızca CLP ile ilişkili olduğunu gösteren CL ve CLP için ayrı analizler de gerçekleştirmiştir.

Gelecekteki çalışmalar için gerekli olan diğer araştırma temaları arasında fenotipik ve etnik çeşitliliğin çalışmalara dâhil edilmesi, gen etkileşimleri yoluyla yolların ve genin incelenmesi, fonksiyonel varyantların belirlenmesi ve etiyolojik öneminin anlaşılması ve nihayetinde bu sonuçların yarık dudak ve yarık damağın dünya çapında klinik yönetimine çevrilmesi yer almasıdır.

NSCL/P hastalarında karyotip sapmalarıyla bozulan aday genlere veya lokuslara odaklanarak bunları tanımlamak için ilişkilendirme çalışmaları yapılmıştır.

Bu çalışmanın amacı, daha önce Avrupa ve Asya örneklerinde tespit edilen risk lokuslarının Türk populasyonunda NSCL/P etiyolojisinde de rol oynayıp oynamadığını belirlemek ve böylece orofasiyal yark genetiğinin populasyon spektrumunu genişletmektir. 


\section{Gereç ve Yöntemler}

Çalışma Trakya Üniversitesi Tıp Fakültesi Bilimsel Araştırmalar Etik Kurulu tarafindan onaylanmıştır. Tüm hasta örnekleri 2016 ile 2020 yılları arasında Trakya Üniversitesi Tip Fakültesi Tibbi Genetik Ana Bilim Dalına yönlendirilen hastaların periferik kan örneklerinden oluşmaktadır. Vakalar için dâhil edilme kriterleri 1-15 yaş arası NSCL/P çocuklardı. NSCL/P vakaları için dışlama kriterleri, sadece yarık damaklı olanlar ve ektodermal displazi veya Axenfeld-Rieger sendromları gibi diğer sendromları olan hastalardı. Olas1 spesifik bir malformasyon sendromu olan hastalar ve zeka geriliği veya diğer anomalileri olan hastalar çalışma dışı birakıldı. Hem probandlar hem de velileri, kapsamlı araştırma prosedürü hakkında bilgilendirilmiş ve bu çalışmaya kaydedilmeden önce bilgilendirilmiş onam imzalamışır. 18 yaşından küçük katılımcıların onayı ebeveynlerden alındı. Hastalar klinik olarak değerlendirildi ve altta yatan bir sendromu düşündüren herhangi bir anormalliği belirlemek için ayrıntılı bir anket dolduruldu.

T1bbi kayıtları kontrol ederek veya katılımcıların vasileriyle görüşerek tüm vakaların ve kontrollerin genetik olarak ilgisiz olduğunu gördük. Hastalardan EDTA'lı tüpe alınan 2 cc periferik venöz kandan genomik DNA izolasyonu yapılarak, aCGH çalışması gerçekleştirildi. Oligonucleotide aCGH, üreticinin protokolüne göre 180.000 oligonucleotide microarray (Sure Print G3 Human 4x180k CGH Mikroarray Kiti, Agilent Technologies, Santa Clara, CA) ile lenfositlerden ekstrakte edilen gDNA'lar üzerinde gerçekleştirildi. $4 \times 180 \mathrm{~K}$ platformu, ortalama mekânsal çözünürlüğü $13-25 \mathrm{~kb}$ olan 170.000 'den fazla 60 -mer oligonükleotid probundan oluşur. Slaytlar, Agilent mikrodizi taray1c1 G2565CA üzerinde tarand1. Görüntü verileri çıkarıldı ve Feature Extraction Agilent Technologies (9.5.3.1) ile metin dosyalarına dönüştürüldü. Anormal bir log oranı veren en az üç bitişik oligonükleotidin, bir kopya sayısı değişikliğini (copy number variation, CNV) işaret ettiği düşünülmüştür. Sonuçlar hg19 genom versiyonunda verilmektedir. CNV'nin heterozigot bir delesyonun olarak tanımlanması için log2ratio Cy5 / Cy3'ün - 0.8 ila 1 olması beklenir.

\section{İstatistiksel Analiz}

İzole yarık damak ve dudak bulgusu ile 17 hasta çalışmaya dâhil edilmiştir. Kategorik değişkenlerin (cinsiyet) gruplara göre karşılaştırılmasında Ki-kare analizi kullanıldı. İstatistiksel anlamlllık düzeyi $\mathrm{p}<0.05$ olarak kabul edildi.

Verilerin değerlendirilmesinde IBM SPSS Statistics 21.00 paket programı kullanıldı. Olguların demografik özellikleri, elde edilen veriler SPSS programına kaydedildi.

\section{Bulgular}

Hasta grubunda en küçük bir ay, en büyük 180 ay olmak üzere ortalama yaş $\sim 38,04$ ay saptand. Hasta grubunda dokuz (\%52.94) erkek, sekiz (\%47.05) kadın olmak üzere 17 yarık damak ve/veya yarık dudaklı olgu mevcuttu. Her iki grubunu cinsiyet dağılımlarının homojen olduğu gözlenmektedir $\quad(p=1) . \quad$ Olguların ebeveynlerinin hiçbirinde akraba evliliği öyküsü saptanmadı.

On yedi hastanın yedisinde $(\% 41,17) 547 \mathrm{~kb}$ ila $10 \mathrm{Mb}$ arası büyüklükte $\mathrm{CNV}$ saptandı (Tablo 1). Hastaların majör ve minör bulguları ile aCGH analizi sonuçları Tablo 1'de yer almaktadır. Sekiz patojenik CNV 'nin hepsi denovo olarak tespit edilmiştir. Bir hastamızda farklı iki kromozomda varyasyon saptanmıştır. 
Tablo 1: Hasta grubumuzun endikasyonları ve a-CGH sonuçları

\begin{tabular}{|c|c|c|c|c|c|}
\hline $\begin{array}{l}\text { Hasta } \\
\text { no }\end{array}$ & Cinsiyet & Endikasyon & $\begin{array}{l}\text { Kromozomal } \\
\text { Değişim Bölgesi }\end{array}$ & $\begin{array}{l}\text { Kromozomal } \\
\text { Değişim } \\
\text { Büyüklüğü }\end{array}$ & $\begin{array}{l}\text { Kromozomal } \\
\text { Değişim Türü }\end{array}$ \\
\hline 1. & $\mathrm{~K}$ & $\begin{array}{l}\text { Konuşma geriliği + Opere yarık } \\
\text { damak/dudak }\end{array}$ & $6 \mathrm{p} 22.3-23$ & $10747 \mathrm{~kb}$ & Delesyon \\
\hline 2. & $\mathrm{E}$ & Dudak/damak yarığı & Normal & & \\
\hline 3. & $\mathrm{E}$ & Dudak/damak yarığı & 9 p23-p24 & $547 \mathrm{~kb}$ & Duplikasyon \\
\hline 4. & $\mathrm{E}$ & Epikantus, yarık damak/dudak & Normal & & \\
\hline 5. & $\mathrm{E}$ & Dudak/damak yarığı & Normal & & \\
\hline 6. & $\mathrm{E}$ & Dudak yarığı/damak & Normal & & \\
\hline 7. & $\mathrm{~K}$ & Yarık damak/dudak, retromikrognati & $18 \mathrm{q} 12.1$ & $2,282.338 \mathrm{~kb}$ & Duplikasyon \\
\hline 8. & $\mathrm{~K}$ & Dudak-damak yarığı & Normal & & \\
\hline 9. & $\mathrm{~K}$ & $\begin{array}{l}\text { Yarı dudak /damak, up-slanting } \\
\text { palpebral fissür, retrognati }\end{array}$ & $5 q 21.3$ & $1,830.984 \mathrm{~kb}$ & Delesyon \\
\hline 10. & $\mathrm{~K}$ & Yüksek damak, yarık damak/dudak & Normal & & \\
\hline 11. & $\mathrm{E}$ & $\begin{array}{l}\text { Hidrosefali, basık burun kökü, } \\
\text { yüksek damak/dudak }\end{array}$ & Xp22.12 & $192.882 \mathrm{~kb}$ & Duplikasyon \\
\hline 12. & $\mathrm{~K}$ & $\begin{array}{l}\text { Yüksek-dar damak, yarık } \\
\text { damak/dudak }\end{array}$ & Normal & & \\
\hline 13. & E & Yarık damak, dudak, & $\begin{array}{l}\text { Yq11.21 } \\
16 q 24.1\end{array}$ & $\begin{array}{l}476.899 \mathrm{~kb} \\
94.361 \mathrm{~kb}\end{array}$ & Duplikasyon \\
\hline 14. & $\mathrm{~K}$ & Yarık damak dudak & $\mathrm{Xp} 22.31$ & $1,608.791 \mathrm{~kb}$ & Duplikasyon \\
\hline 15. & $\mathrm{E}$ & Yarık dudak ve damak & Normal & & \\
\hline 16. & $\mathrm{~K}$ & Damak/dudak yarığı, retromikrognati & Normal & & \\
\hline 17. & $\mathrm{E}$ & $\begin{array}{l}\text { Retro-mikrognati, damak agenezisi, } \\
\text { anvert burun delikleri, dış kulak yolu } \\
\text { anomalisi, damak/dudak yarığı, }\end{array}$ & Normal & & \\
\hline
\end{tabular}

\section{Tartışma ve Sonuç}

Dudak damak yarıklarının ortaya çıkmasında birçok genetik ve çevresel faktör karş1lıklı etkileşim halinde birlikte rol oynar. Nonsendromik dudak ve damak yarıkları belirgin bir genetik altyapıya sahiptir. Collins ve ark., nonsendromik dudak damak yarığı gelişimi ile bağlantılı 16 adet gen bölgesi tanımlamışlardır ${ }^{22}$. IRF6 genindeki polimorfizm nonsendromik dudak damak yarığı gelişimi için güçlü derecede ilişkili bulunmuştur $^{23}$. Ayrica MSX1, PVRL1, FGFR2, PAX7, NOG ve SPRY2 genleri de daha zayıf olmakla birlikte ilişkili bulunmuştur. $1,2,4,6,14,17$ ve 19 . kromozomlardaki defektlerin (MTHFR, TGFA, D4S175, F13A1, TGFB3, D17S250, ve $A P O C 2$ genlerin) dudak ve damak yarığı ile ilişkili olduğu bulunmuştur ${ }^{24-26}$.
Çalışmamızda, izole opere edilmiş yarık damak/dudak ve konuşma geriliği ile Genetik Hastalıklar Tanı Merkezimize müracaat eden altı yaşındaki erkek hastamızda, 6p22.3-23 delesyonu saptanmıştır. Orofasial yarıklarla bağlantılı ilk genomik bölge, kromozom 6p üzerindeki $F 13 A$ lokusu olarak bildirilmiştir ${ }^{27}$. Ek bağlantı çalışmaları (insan genomunun haritalanmasıyla desteklenen) daha başarılı oldu ve CL/P ile ilişkili altı kromozomal bölge bulunmuştur (1q32, 6p23, 6q23-25, $9 q 21,14 q 21-24$ ve 15q15). Bu bölgelerdeki genleri değerlendiren tamamlayıcı çalışmalarla, bu bölgeler CLP'ye önemli katkıda bulunanlar olarak daha da desteklenmiştir ${ }^{28}$. 
Literatür taramaları sonucunda; $C L P$ geninin altıncı kromozom (OCF1 olarak adlandırılır) üzerindeki lokalizasyonunu çelişkili sonuçlarla bildirildiği belirlenmiştir. NSCL/P'nin, kromozom altının (6p) k1sa kolunu içeren kromozomal anormalliklerle ilişkili olduğu rapor edilmiştir. İlgili lokuslar, $H G P 22$ ve $A P 2$ genlerinin yakınındaki $6 \mathrm{p} 24.3$ bölgesi olarak düşünülmüştür. Sendromik olmayan 21 farklı CLP İtalyan aile üzerine yapılan bir araştırmada, 6p23 bölgesinde bu anomaliyle bağlantı gözlenmiştir ${ }^{29}$.

Dudak/damak yarığı bulguları ile tarafimıza müracaat eden yeni doğan dönemindeki bir başka hastamızda, 9p24-p23 kromozomal bölgesinde $547 \mathrm{~kb}$ büyüklügünde artış saptanmıştır. $\mathrm{Bu}$ artış PTPRD genini içine almaktaydı. Daha önce tek bir çalışmada yarık damak ve dudak ile ilişkilendirilmiştir ${ }^{30}$. Fakat bu çalışmada bildirilen bu geni içine alan kromozomal bölgenin delesyonudur. $\mathrm{Bu}$ açıdan bulgumuz literatürde yardık damak ve dudakla ilişkili olduğu öngörülen ilk veridir. PTPRD, hipokampal CA2 ve CA3 dahil olmak üzere beynin özel bölgelerinde, B lenfositlerinde ve timik medullada eksprese edilen reseptör tipi bir protein-tirozin fosfatazdır. Klinikte PTPRD genindeki varyasyon ile huzursuz bacak sendromu arasındaki olası bir ilişki olduğu bildirilmiştir.

Yarı dudak/damak, retromikrognati nedeniyle değerlendirilen yenidoğan grubundan k1z bebekte 18q12.1 bölgesinin duplikasyonu saptanmıştır. 18.kromozomdaki değişimlerle ilgili olarak özellikle duplikasyon durumlarında klinik etkinin asıl sorumlusunun 18q11-q13 and 18q22-qter bölgeleri olduğu bildirilmiştir $^{31}$.

Mewar ve ark. çalışmasında dört hastanın sitogenetik olarak belirlenen kırılma noktalarının karşılaştırılması ile ortak kopyalanan bölgenin 18q12-q22 olduğunu göstermiştir. $\mathrm{Bu}$ kromozomal bölgenin, tüm bireyler tarafindan paylaşılan klinik özelliklerden, büyüme geriliği, zihinsel ve gelişimsel gecikmeler ve muhtemelen nöbetler gibi özelliklerden sorumlu olabileceğini bildirmişlerdir. Bununla birlikte, Edwards sendromunun birçok özelliğine sahip hastaların her ikisinin de $18 \mathrm{q}$ bölümleri için trizomik iken diğer kromozomal bölgeler için monozomik olduğunu belirtmişlerdir ${ }^{32}$. PubMed yer alan literatürlerde ve DECIPHER veri tabanının araştırılması, vakamızla örtüşen 18q12.1'de değişim içeren 4 ek vaka belirledi (bir duplikasyon, iki delesyon ve bir dengeli translokasyon). Özellikle, otizm ve entelektüel yetmezlikte, $18 \mathrm{q} 12.1$ 'de genomik kazanç veya kayıp, ayrıca duplikasyon vakalarında epilepsi ve kısa boy ve delesyon vakalarında hipotoni ve uzun boy ile görülür. İncelenen vakalar arasında tutarlı bir dismorfik özellik kaydedilmemiştir ${ }^{33}$. Bu nedenle yarık damak ve dudak ile 18q12.1 kazancı ya da kaybı bağdaştırılamamıştır.

Yarık damak, up-slanting palpebral fissür, hipertelorizm, retrognati bulguları olan başka bir yenidoğan hastamızda 5q21.3 bölgesinin 1,8 Mb'lık delesyonu saptanmıştır. Hastamızda saptadığımız delesyon bölgesine dört adet gen (FBXL17, FER, EFNA5, LINC01023) tekabül etmektedir. Clinvar veritabanında FBXL17, FER, EFNA5 delesyonları için klinik önemi bilinmeyen (VUS) olarak giriş yapılmasına rağmen davranışsal anormallik ve gelişimsel gecikmede bildirilmiştir ${ }^{34}$. OMIM, FER geni için, doğuştan gelen bağışıklığın düzenlenmesinde bir rolü olduğunu bildirmektedir ${ }^{35}$. FBXL17 gibi F-box protein ailesinin üyeleri, yaklaşık olarak 40 amino asitlik bir F-kutusu motifi ile karakterize edilmektedir $^{36}$. Efrin gen ailesinin bir üyesi olan EFNA5, geç evre sinir sistemi gelişimi ve farklılaşması modeli olan kortikal nöronların astrositlerle birlikteki kültürlerinde akson demetlenmesini önler. EFNA5, diğer dokularda daha düşük ifade edilmekle birlikte, insan beyni, kalp, plasenta, akciğer ve böbrekte yüksek oranda ifade olmaktadır ${ }^{37}$. LINC01023 geni için ise literatürde, IGF1R / AKT sinyal yolağının aktivasyonu yoluyla gliomada onkojenik bir rol oynadığ bildirilmiştir $^{38}$. Hastamızın delesyon bölgesinde bulunan bu genler ile ilgili bildirilen fenotiplerde yarık damak dudak yer almamaktadır. Lei ve ark. nın yaptıkları çalışmada orafasial yarık hastalarında 5q21.1 bölgesinde delesyon saptanmıştır. Bu bölgede bulunan PAM (MIM 170270) geninin tek kopya olarak taşındığ bildirilmiştir $^{39}$.

Tonk ve ark'nın yaptığı başka bir çalışmada hafif motor geriliği, müteakip öğrenme 
farkl111kları, nöbetler ile kromozomal $5 \mathrm{q} 14.3 \mathrm{q} 21.3$ delesyonu olan bir hastay1 bildirmişlerdir. Her iki çalışmada da yarık damak dudak anomalisi bildirilmemiştir ${ }^{40}$.

Hidrosefali, hidrosel, basık burun kökü, yarık damak/dudak bulgusu olan 2 yaşındaki erkek hastada $192 \mathrm{~kb}$ büyüklüğünde Xp22.12 duplikasyonu saptanmıştır. Olgumuza benzer duplikasyon bölgesi olan bir başka olgu literatürde; Lintas ve ark. tarafindan Xp22.33p22.12 kromozomunda denovo $19 \mathrm{Mb}$ duplikasyonu olan, şiddetli zihinsel engel, konjenital hipotoni ve belirgin glabella, kısa filtrum, mikrognati, yüksek alın dahil olmak üzere hipertelorizm, epikantal kıvrımlar, aşağ 1 eğimli palpebral fissürler, geniş burun köprüsü ve kısa üst dudak dismorfik özelliklerden etkilenen 30 yaşındaki bir erkeği bildirilmiştir ${ }^{41}$.

Hastamizın delesyon bölgesinde PDHA1 ve MAP3K15 genleri yer almaktadır. Bu genlere ait ClinVar veritabanında konjenital sinir sistemi bozukluğu ile birlikte yumuşak damak yarığının eşlik ettiği olgular bildirilmiştir.

Yenidoğan anomalisi olan ve $\sim 1,6 \mathrm{Mb}$ büyüklüğünde $\mathrm{Xp22.31}$ duplikasyonu olan diğer bir hastamızda izole yarık damak dudak tespit edilmiştir. Daha önce bildirilen olgular araştırıldığında Liu ve ark. Xp22.31 ekstra kopyasının, anormal fenotipler için bir risk faktörü olarak hizmet edebileceğini savunmuşlardır ${ }^{42}$.

Yarık damak, dudak ile araştırmaya dâhil olan son hastamız erkek yenidoğan döneminde bir olguydu. Hastada yapılan a-CGH analizi sonucunda Yq11.21/16q24.1 bölgelerinin duplikasyonu saptanmıştır. 16q24.1 de gözlenen artış $94 \mathrm{~kb}$ büyüklüğünde $A T P 2 C 2$ ve $T L D C 1$ genlerini kapsamaktayd. Yq11.21 bölgesindeki artış $476 \mathrm{~kb}$ büyüklüğünde ve üç gen bölgesini içine alıyordu (USP9Y, GYG2P1,TTTY15). Kromozomal kazanım bölgelerinde yer alan genler detaylı incelendiğinde; ATP2C2 ve TTTY15 yarık damak dudak anomalisi ile ilişkilendirilmiştir ${ }^{43}$. Ek olarak USP9Y-TTTY15 füzyon transkriptleri, transkripsiyon aracilı kimerik RNA'lar olarak bilinir. Prostat kanseri dâhil olmak üzere çeşitli kanser türleri arasında tümörijenik yolaklarda yer aldığı bildirilmiştir ${ }^{44}$.

\section{Sonuç}

Orofasial yarıklar hem psikolojik hem de fiziksel sorunlara neden olduğu için ciddi bir doğumsal defekttir. Etyolojisindeki müphem durum bu patolojinin daha fazla araştırılmasını gerektirmektedir. Epidemiyolojik ve deneysel çalışmalar çevresel faktörlerin yarık damak dudak geliş̧iminde etkili olduğunu göstermiştir. Hamilelik sırasında, annenin tütün ve alkol kullanımı, malnütrisyon, viral enfeksiyonlar, ilaç kullanımı embriyo üzerinde teratojenik etki gösterirler. Etyoloji de sorumlu genetik ve çevresel faktörlerin daha geniş bir toplumda çalışılması gerekmektedir. Özellikle genetik ve çevresel faktörlerin birlikte analiz edilmesi bu konudaki problemlerin çözümüne daha fazla katkıda bulunacaktır. Bütün bu gelişmeler; genetik taramalarda daha kesin metodlara izin vererek yüksek riskli bireylerin veya aile gruplarının ortaya çıkarılmasını ve erken prenatal teşhis konmasını sağlayacaktır. Etyolojinin tespiti ile risk gurubundaki aileler prekonsepsiyonel dönemde detaylı olarak bilgilendirilmeli ve risk faktörleri anlatılmalıdır. Günümüzdeki tedavi yöntemleri de etyolojide sorumlu genlerdeki düzensizlik sorununu çözerek çözüm bulmaya çalışmaktadır

Hasta Onami: Yazll hasta onamı bu çalışmaya katılan hastaların ebeveynlerinden alınmiştır.

\section{KAYNAKLAR}

1. Nazer J, Ramirez MC, Cifuentes L. Evolution of prevalence rates of orofacial clefts in a maternity of a Chilean clinical hospital. Rev Med Chil. 2010;138: 567-72.

2. Rahimov F, Jugessur A, Murray JC. Genetics of nonsyndromic orofacial clefts. Cleft Palate Craniofacial Journal. 2012; 49:73-91. 
3. Christensen K, Juel K, Herskind AM et al. Long term follow up study of survival associated with cleft lip and palate at birth. BMJ. 2004; 328:1405.

4. Menezes R, Marazita ML, Goldstein McHenry T et al. AXIS inhibition protein 2, orofacial clefts and a family history of cancer. $J$ Am Dent Assoc. 2009; 140:80-84.

5. Dietz A, Pedersen DA, Jacobsen R et al. Risk of breast cancer in families with cleft lip and palate. Ann Epidemiol. 2012; 22:37-42.

6. Tunçbilek G, Özgür F, Balcı S. 1229 yarık dudak ve damak hastasında görülen ek malformasyon ve sendromlar. Çocuk Sa ̆̆lı̆̆l ve Hastalıkları Dergisi, 2004; 47: 172-6.

7. Jugessur A, Farlie PG, Kilpatrick N. The genetics of isolated orofacial clefts: from genotypes to subphenotypes. Oral Dis. 2009a; 15:437-453.

8. Jensen BL, Kreiborg S, Dahl E et al. Cleft lip and palate in Denmark, 1976-1981: epidemiology, variability, and early somatic development. Cleft Palate J. 1988; 25:258-269.

9. Mossey PA, Little J, Munger RG et al. Cleft lip and palate. Lancet. 2009; 374: 1773-1785.

10. Gundlach KK, Maus C. Epidemiological studies on the frequency of clefts in Europe and worldwide. J Craniomaxillofac Surg. 2006; 34(Suppl 2): $1-2$.

11. Dixon MJ, Marazita ML, Beaty TH et al. Cleft lip and palate: understanding genetic and environmental influences. Nat Rev Genet. 2011; $12: 167-178$.

12. Tomatır AG, Demirhan H, Sorkun HÇ et al. Major congenital anomalies: a five year retrospective regional study in Turkey. Genet Mol Res 2009;8:19-27.

13. Sivertsen A, Wilcox AJ, Skjaerven $R$ et al. Familial risk of oral clefts by morphological type and severity: population based cohort study of first degree relatives. BMJ. 2008; 336:432-434.

14. Marazita ML. The Evolution of Human Genetic Studies of Cleft Lip and Cleft Palate. Annu Rev Genomics Hum Genet. 2012;13.263-83.

15. Marazita ML, Murray JC, Lidral AC et al. Metaanalysis of 13 genome scans reveals multiple cleft lip/palate genes with novel loci on 9 q21 and $2 q 32$ 35. Am J Hum Genet. 2004; 75:161-173.

16. Letra A, Menezes R, Govil M et al. Follow-up association studies of chromosome region $9 \mathrm{q}$ and nonsyndromic cleft lip/palate. Am J Med Genet A. 2010; 152A:1701-1710.

17. Beaty TH, Ruczinski I, Murray JC et al. Evidence for gene-environment interaction in a genome wide study of nonsyndromic cleft palate. Genet Epidemiol. 2011; 35: 469-478.

18. Birnbaum S, Ludwig KU, Reutter $\mathrm{H}$ et al. Key susceptibility locus for nonsyndromic cleft lip with or without cleft palate on chromosome 8q24. Nat Genet. 2009; 41:473-477.

19. Grant SF, Wang K, Zhang H et al. A genomewide association study identifies a locus for nonsyndromic cleft lip with or without cleft palate on 8q24. J Pediatr. 2009; 155:909-913.

20. Ludwig KU, Mangold E, Herms $S$ et al. Genomewide meta-analyses of nonsyndromic cleft lip with or without cleft palate identify six new risk loci. Nat Genet. 2012 ;44:968-71
21. Mangold E, Ludwig KU, Birnbaum $\mathrm{S}$ et al. Genomewide association study identifies two susceptibility loci for nonsyndromic cleft lip with or without cleft palate. Nat Genet. 2010; 42:24-26.

22. Collins A, Arias L, Pengelly R et al. The potential for next generation sequencing to characterise the genetic variation underlying nonsyndromic cleft lip and palate phenotypes. OA Genet 2013; 1: 10.

23. Zucchero TM, Cooper ME, Maher BS et al. Interferon Regulatory Factor 6 (IRF6) Gene Variants and the Risk of Isolated Cleft Lip or Palate. N Engl J Med 2004; 351: 769-80.

24. Lidral AC, Romitti PA, Basart AM et al. Association of MSX1 and TGFB3 with Nonsyndromic Clefting in Humans. Am J Hum Genet 1998; 63: 557-68.

25. Van Den Boogaard MJH, Dorland M, Beemer FA et al. MSX1 mutation is associated with orofacial clefting and tooth agenesis in humans. Nat Genet 2000; 24: 342-3.

26. Leslie EJ, Marazita ML. Genetics of cleft lip and cleft palate. Am J Med Genet Part C Semin Med Genet 2013; 163: 246-58.

27. Eiberg H, D Bixler, LS Nielsen, et al. Suggestion of linkage of a major locus for nonsyndromic orofacial cleft with F13A and tentative assignment to chromosome 6. Clin Genet 32: 129-132.

28. Marazita ML, JC Murray, AC Lidral et al. Metaanalysis of 13 genome scans reveals multiple cleft lip/palate genes with novel loci on $9 \mathrm{q} 21$ and $2 \mathrm{q} 32-$ 35. Am J Hum Genet. 2004 Aug;75:161-73.

29. Carinci F, Pezzetti F, Scapoli L et al. Nonsyndromic cleft lip and palate: evidence of linkage to a microsatellite marker on $6 \mathrm{p} 23 \mathrm{Am} \mathrm{J}$ Hum Genet. 1995 ;56:337-9.

30. Ann LL. "The role of structural variation in cleft lip and palate." $\mathrm{PhD}$ (Doctor of Philosophy) thesis, University of Iowa, 2018.

31. Turleau C, Chavin-Colin F, Narbouton R et al. Trisomy 18q-: trisomy mapping of chromosome 18 revisited. Clin Genet.1980;18: 20-26

32. Mewar R, Kline AD, Harrison $\mathrm{W}$ et al. Clinical and molecular evaluation of four patients with partial duplications of the long arm of chromosome 18. Am J Hum Genet. 1993 ;53:126978.

33. Wang $\mathrm{P}$, Carrion $\mathrm{P}$, Qiao $\mathrm{Y}$ et al. Genotypephenotype analysis of $18 \mathrm{q} 12.1-\mathrm{q} 12.2$ copy number variation in autism. Eur $J$ Med Genet. 2013 ;56:420-5

34. National Center for Biotechnology Information. ClinVar; [VCV000441691.1], https://www.ncbi.nlm.nih.gov/clinvar/variation/V CV000441691.1 (accessed May 11, 2021).

35. Morris C, Heisterkamp N, Hao QL et al. The human tyrosine kinase gene (FER) maps to chromosome 5 and is deleted in myeloid leukemias with a del(5q). Cytogenet. Cell Genet. 1990; 53: 196-200.

36. Jin J, Cardozo T, Lovering RC et al. Systematic analysis and nomenclature of mammalian F-box proteins. Genes Dev. 2004;18: 2573-2580.

37. Winslow JW, Moran P, Valverde $\mathrm{J}$ et al. Cloning of AL-1, a ligand for an Eph-related tyrosine kinase receptor involved in axon bundle formation. Neuron. 1995; 14: 973-981. 
38. $\mathrm{Yu} \mathrm{M}, \mathrm{Yu} \mathrm{S}$, Gong $\mathrm{W}$ et al. Knockdown of linc01023 restrains glioma proliferation, migration and invasion by regulating IGF-1R/AKT pathway. J Cancer. 2019;10:2961-2968.

39. Lei TY, Wang HT, Li F et al. Application of high resolution SNP arrays in patients with congenital oral clefts in south China. $J$ Genet. 2016 Dec;95:801-809.

40. Tonk V, Kyhm JH, Gibson $\mathrm{CE}$ et al. Interstitial deletion 5q14.3q21.3 with MEF2C haploinsufficiency and mild phenotype: when more is less. Am J Med Genet A. 2011 Jun;155A:1437-41.

41. Lintas C, Picinelli C, Piras IS et al. Xp22.33p22.12 Duplication in a Patient with Intellectual Disability and Dysmorphic Facial Features. Mol Syndromol. $2016 ; 6: 236-41$.

42. Liu P, Erez A, Nagamani SC et al. Copy number gain at Xp22.31 includes complex duplication rearrangements and recurrent triplications. Hum Mol Genet. 2011 15;20:1975-88.

43. Buniello A, MacArthur JAL, Cerezo $M$ et al. The NHGRI-EBI GWAS Catalog of published genome-wide association studies, targeted arrays and summary statistics 2019. Nucleic Acids Research, 2019, Vol. 47 (Database issue): D1005D1012.

44. Kasajima R, Yamaguchi R, Shimizu E et al. Variant analysis of prostate cancer in Japanese patients and a new attempt to predict related biological pathways. Oncol Rep. 2020 ;43:943952. 